\title{
Proton-Conductive Composites Composed of Phosphoric Acid-Doped Silica Gel and Organic Polymers with Sulfo Groups
}

\author{
Atsunori MATSUDA, Kazuki HIRATA, Masahiro TATSUMISAGO and Tsutomu MINAMI \\ Department of Applied Materials Science, Graduate School of Engineering, Osaka Prefecture University, \\ 1-1, Gakuen-cho, Sakai-shi, Osaka 599-8531
}

\section{リン酸を添加したシリカゲルとスルホ基を有する有機高分子からなるプロトン伝導性複合体 松田厚範・平田和希・辰巳砂昌弘・南 努 \\ 大阪府立大学大学院工学研究科機能物質科学分野, 599-8531 大阪府堺市学園町 1-1}

\begin{abstract}
Preparation of highly proton-conductive and thermoplastic composites was successfully pursued from $\mathrm{H}_{3} \mathrm{PO}_{4}$-doped silica gel and organic polymers with sulfo groups. The sulfo groups and polystyrene blocks in the organic polymers were found to improve the proton conductivity and molding characteristics of the resultant composite, respectively. The composite composed of $\mathrm{H}_{3} \mathrm{PO}_{4}$-doped silica gel with a molar ratio $=0.5$ of $\mathrm{H}_{3} \mathrm{PO}_{4} / \mathrm{SiO}_{2}$ in 80 mass \% and sulfonated styrene-isoprene-styrene ( $\mathrm{SIS}-\mathrm{SO}_{3} \mathrm{H}$ ) block copolymer in 20 mass $\%$ showed a high electrical conductivity of $10^{-4} \mathrm{~S} \cdot \mathrm{cm}^{-1}$ at $25^{\circ} \mathrm{C}$ in dry $\mathrm{N}_{2}$ atmosphere and good molding characteristics. The temperature dependence of the electrical conductivity of the composite was of the Vogel-Tamman-Fulcher type, indicating that proton transferred through a liquid-like phase present in the composites consisting of silica gel and organic polymer. The elastic modulus of the composite was larger by one to two orders of magnitude than that of the $\mathrm{SIS}-\mathrm{SO}_{3} \mathrm{H}$ elastomer. The thermoplastically deforming temperature of the composite was around $130^{\circ} \mathrm{C}$, which was higher by $50^{\circ} \mathrm{C}$ than that of the SIS elastomer itself. The capacitance of a totally solid state electric double-layer capacitor, which was fabricated using the composite as a solid electrolyte, was comparable to those of the conventional capacitors with liquid electrolytes. [Received August 16, 1999; Accepted September 14, 1999]
\end{abstract}

Key-words : Sol-gel method, Proton conductivity, Phosphoric acid, Elastomer, Sulfo group, Electric double layer capacitor

\section{Introduction}

Recently electrochemical devices which convert chemical energy directly to electrical one have been extensively studied from a viewpoint of environment protection since they are expected as clean power sources to reduce the amounts of air pollutants and hazardous substances generated from the combustion of fossil fuels. ${ }^{1)}$ Solid state proton conductors are key materials for the electrochemical power devices such as fuel cells, metal hydride batteries, and supercapacitors. ${ }^{2)-5}$ ) The gel materials, which are apparently "solid," prepared by the sol-gel method contain a large number of micropores and mesopores filled with "liquid." The gel materials are thus expected to be fast proton conductors by doping an electrolyte into the pores. ${ }^{6)}$ On the basis of the expectation above, we prepared the silica gels containing several kinds of acids and salts as an electrolyte by the sol-gel method and demonstrated that protonic acids with hydrated water acted as effective proton donors to improve the conductivity. ${ }^{7)-9)}$ Moreover we have applied the proton-conducting gels to the electrochemical devices such as electrochromic cells ${ }^{10)}$ and capacitors. ${ }^{11)}$ Very recently we have fabricated composites composed of $\mathrm{H}_{3} \mathrm{PO}_{4}$-doped silica gel and styrene-ethylene-butylene-styrene (SEBS) elastomer for the improvement of the molding properties ${ }^{12}$ ) and for the application to the totally solid-state electric double-layer capacitors as a solid electrolyte. ${ }^{13)}$

In the preceding work, ${ }^{12), 13)}$ we selected SEBS elastomer as a binder to fill up the voids between the silica grains, and we found that SEBS elastomer provided the resultant composites with good molding characteristics. In the present work, we have designed the sulfonated organic polymer, which is expected to assist the proton conduction in the composite as well as good molding characteristics due to the thermoplasticity. This paper reports the proton conductivity and thermoplastic properties of the composites compos- ed of $\mathrm{H}_{3} \mathrm{PO}_{4}$-doped silica gel and sulfonated organic polymer. In addition, characteristics of the totally solid state electric-double layer capacitor fabricated using the composite as an electrolyte and activated carbon powders as polarizable electrode are reported.

\section{Experimental procedure}

2.1 Preparation of composites

Silica sols were prepared from tetraethoxysilane $\left(\mathrm{Si}(\mathrm{OEt})_{4}\right)$, ethanol $(\mathrm{EtOH}), \mathrm{H}_{2} \mathrm{O}$ containing $\mathrm{HCl}$ as a catalyst, and $\left[\left(\mathrm{C}_{2} \mathrm{H}_{5}\right)_{4} \mathrm{~N}\right] \mathrm{BF}_{4}$ in a molar ratio of $\mathrm{Si}(\mathrm{OEt})_{4}$ : EtOH : $\mathrm{H}_{2} \mathrm{O}: \mathrm{HCl}:\left[\left(\mathrm{C}_{2} \mathrm{H}_{5}\right)_{4} \mathrm{~N}_{3} \mathrm{BF}_{4}=1: 4: 8: 0.01: 0.01\right.$.

$\left[\left(\mathrm{C}_{2} \mathrm{H}_{5}\right)_{4} \mathrm{~N}\right] \mathrm{BF}_{4}$ was used to shorten the gelation time. After mixing these components at room temperature, $\mathrm{H}_{3} \mathrm{PO}_{4}$ was added to the mixture. The resultant solution was stirred continuously at room temperature until gelation occurred. The $\mathrm{H}_{3} \mathrm{PO}_{4} / \mathrm{SiO}_{2}$ molar ratio was fixed to be 0.5 .

$\mathrm{H}_{3} \mathrm{PO}_{4}$-doped silica bulk gels obtained were dried in vacuo at $60-80^{\circ} \mathrm{C}$ for $8 \mathrm{~h}$ and heat-treated at $150^{\circ} \mathrm{C}$ for $1 \mathrm{~h}$. The dried gels were ground to be powders of 10 to $80 \mu \mathrm{m}$.

Polyisoprene (PI) and styrene-isoprene-styrene block copolymer (SIS) were selected as the base polymers to be sulfonated (Scheme 1). The average molecular weights of PI and SIS were 40000 and 220000 , respectively. The styrene/isoprene mole ratio in SIS was $22 / 78$. The specific gravity of the SIS was 0.90 . Sulfonation ratios were varied from 0 to $50 \%$ for PI and from 0 to $20 \%$ for SIS (Table 1), where the ratio was defined as a percentage of the amount of $\mathrm{SO}_{3} \mathrm{H}$ groups to the total amounts of hydrogens and $\mathrm{SO}_{3} \mathrm{H}$ groups represented as $\mathrm{X}$ in Scheme 1. PI without sulfonation was used as a dioxane solution. Sulfonated polyisoprene $\left(\mathrm{PI}-\mathrm{SO}_{3} \mathrm{H}\right)$ with the ratio of 5 and $10 \%$ was dissolved in toluene and $\mathrm{PI}-\mathrm{SO}_{3} \mathrm{H}$ with the ratio of 30 and $50 \%$ in water. SIS and sulfonated styrene-isoprene-styrene block copolymer (SIS-SO ${ }_{3} \mathrm{H}$ ) were dissolved in toluene. 
(a) Polyisoprene ( PI)<smiles>[X]C(C)(C=CC(C)(C)C)CC(C)(C)C</smiles>

$\mathrm{X}=\mathrm{H}$ or $\mathrm{SO}_{3} \mathrm{H} \cdot \ldots \mathrm{PI} \cdot \mathrm{SO}_{3} \mathrm{H}$

(b) Styrene-Isoprene-Styrene block copolymer ( SIS )<smiles>[X]C(C)(C=CC(C)(C)C)CC(C)(C)C(C)(C)CC(c1ccccc1)C(CC(C)(C)C)c1ccccc1</smiles>

$\mathrm{X}=\mathrm{H}$ or $\mathrm{SO}_{3} \mathrm{H} \cdot \cdots \mathrm{SIS}-\mathrm{SO}_{3} \mathrm{H}$

Scheme 1

Table 1. Sulfonation Ratios of Base Polymers Used in the Present Study

\begin{tabular}{llllll}
\hline base polymer & \multicolumn{5}{c}{ sulfonation ratio $/ \%$} \\
\hline polyisoprene & 0 & 5 & 10 & 30 & 50 \\
styrene-isoprene-styrene & 0 & & 10 & 20 \\
\hline
\end{tabular}

The solutions containing polymers above were mixed with $\mathrm{H}_{3} \mathrm{PO}_{4}$-doped silica gel powders using an agate mortar in ambient air. The mixing was continued until the solvent completely evaporated. The composites composed of $\mathrm{H}_{3}$ $\mathrm{PO}_{4}$-doped silica gel and the organic polymer above were subsequently pressed at $400 \mathrm{MPa}$ to be a pellet of $13 \mathrm{~mm}$ in diameter and about $1 \mathrm{~mm}$ in thickness. The amount of the organic polymer in the composites was varied from 5 to 20 mass\%. All the composites were dried in vacuo at room temperature for $1 \mathrm{~h}$ before electric and thermo-mechanical measurements.

\subsection{Characterization of composites}

Solid-state ${ }^{31} \mathrm{P}$ NMR spectra were obtained with magic angle spinning (MAS) on a Varian Unity Inova 300 NMR spectrometer operating at $121.419 \mathrm{MHz}$ at a spinning rate of about $5000 \mathrm{~Hz}$ with a $90^{\circ}$ pulse length of $4.0 \mu \mathrm{s}$ and a recycle pulse delay of $30 \mathrm{~s}$. The chemical shifts in NMR spectra were referred to $\mathrm{H}_{3} \mathrm{PO}_{4} 85 \%$ in water. The ionic conductivity was measured for the organic polymers with sulfo groups and the pelletized composites composed of $\mathrm{H}_{3} \mathrm{PO}_{4}$-doped silica gel and the organic polymer using a pair of platinum plates as the electrodes. The conductivity was determined by the impedance data obtained using a Solartron SI 1260 impedance analyzer in a frequency range of $10 \mathrm{~Hz}-8 \mathrm{MHz}$. The elastic modulus of the composites and SIS was determined by the thermo-mechanical analysis using a MAC Science TMA 4000 at a frequency of $0.125 \mathrm{~Hz}$ and a heating rate of $5^{\circ} \mathrm{C} \cdot \mathrm{min}^{-1}$.

2.3 Fabrication of totally solid electric double-layer capacitor

Totally solid state electric double-layer capacitors were fabricated using the composite composed of $\mathrm{H}_{3} \mathrm{PO}_{4}$-doped silica gel and SIS- $\mathrm{SO}_{3} \mathrm{H}$ as an electrolyte and the composite hybridized with activated carbon powders, ACP, as a polarizable electrode. The sulfonation ratio of $\mathrm{SIS}^{-} \mathrm{SO}_{3} \mathrm{H}$ was $20 \%$ and the amount of the SIS- $\mathrm{SO}_{3} \mathrm{H}$ blended was 20 mass \%. The capacitor fabricated had a three layered structure of polarizable electrode part/electrolyte part/polarizable electrode part and was $13 \mathrm{~mm}$ in diameter and about $3 \mathrm{~mm}$ in thickness. The preparation process was essentially the same as described in the preceding paper. ${ }^{12)}$ The feature of the capacitor to be noted is that the large surface area of ACP is covered with the $\mathrm{H}_{3} \mathrm{PO}_{4}$-doped silica gel because ACP were mixed homogeneously with the sol and then gelatinized.

Cyclic voltammetry of the capacitors was carried out to evaluate the capacitor performance using a Hokuto Denko HA-501 potentiostat and a Hokuto Denko HB-301 function generator. The dc resistance of the capacitors fabricated was calculated from an initial voltage drop when the capacitors were discharged. Discharge properties of the capacitors fabricated were also investigated and the capacitance was determined from the discharge curves. The influence of water adsorption to the composites in an ambient atmosphere on the characteristics of the capacitors was also investigated.

\section{Results and discussion}

\subsection{Properties of $\mathrm{H}_{3} \mathrm{PO}_{4}$-doped silica gel}

Preliminary experiment showed that the protonic acids with hydrated water like $\mathrm{H}_{3} \mathrm{PO}_{4}$ acted as an effective proton donor and increased the resultant acid-doped silica gels. ${ }^{9)}$ The $\mathrm{H}_{3} \mathrm{PO}_{4}$-doped silica gel with a $\mathrm{H}_{3} \mathrm{PO}_{4} / \mathrm{SiO}_{2}$ mole ratio of 0.5 was amorphous when the gel was heat-treated at $150^{\circ} \mathrm{C}$. The heat treatment higher than $180^{\circ} \mathrm{C}$ was found to cause the formation of crystalline phases such as $\mathrm{Si}\left(\mathrm{HPO}_{4}\right)_{2} \cdot \mathrm{H}_{2} \mathrm{O}$ and $\mathrm{Si}_{3}\left(\mathrm{PO}_{4}\right)_{4}$, and to decrease the proton conductivity of the gel. ${ }^{12)}$

Figure 1 shows ${ }^{31} \mathrm{P}$ MAS-NMR spectrum of $\mathrm{H}_{3} \mathrm{PO}_{4}{ }^{-}$ doped silica gel with a $\mathrm{H}_{3} \mathrm{PO}_{4} / \mathrm{SiO}_{2}$ mole ratio of 0.5 heattreated at $150^{\circ} \mathrm{C}$. The spectrum was obtained in ambient air at room temperature. A peak of strong intensity at $0 \mathrm{ppm}$ is assigned to $\mathrm{H}_{3} \mathrm{PO}_{4}\left(Q_{0}\right.$ species $)$, indicating that $\mathrm{H}_{3} \mathrm{PO}_{4}$ added is present mainly as orthophosphoric acid in the silica gel. A small peak can be seen at $-11 \mathrm{ppm}$, which is assigned to $Q_{1}$ species with a $\mathrm{P}-\mathrm{O}-\mathrm{Si}$ bond or a $\mathrm{P}-\mathrm{O}-\mathrm{P}$ bond. ${ }^{14)}$

From the IR absorption spectra it was found that an absorption peak at $1020 \mathrm{~cm}^{-1}$ due to $\mathrm{P}-\mathrm{O}-\mathrm{Si}$ bonds was clearly observed in the $\mathrm{H}_{3} \mathrm{PO}_{4}$-doped silica gels heat-treated at

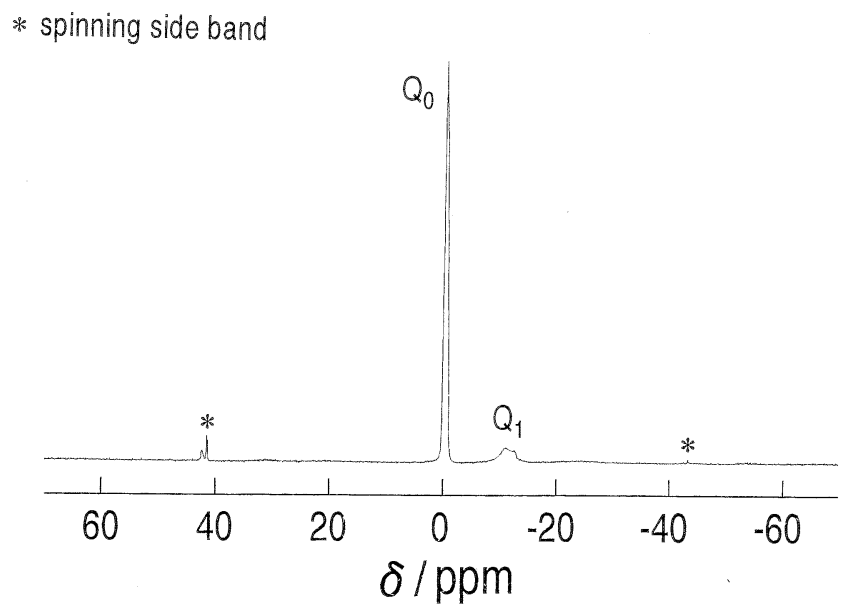

Fig. 1. ${ }^{31} \mathrm{P}$ MAS-NMR spectrum of $\mathrm{H}_{3} \mathrm{PO}_{4}$-doped silica gel with a $\mathrm{H}_{3} \mathrm{PO}_{4} / \mathrm{SiO}_{2}$ molar ratio of 0.5 heat-treated at $150^{\circ} \mathrm{C}$. The spectrum was obtained in ambient air at room temperature. 
$150^{\circ} \mathrm{C}$.

3.2 Properties of organic polymers

The frequency-dependent complex impedance plots were obtained for $\mathrm{PI}-\mathrm{SO}_{3} \mathrm{H}$ with a sulfonation ratio of $50 \%$ and SIS- $\mathrm{SO}_{3} \mathrm{H}$ with a sulfonation ratio of $20 \%$ at room temperature. The ionic conductivities of the $\mathrm{PI}-\mathrm{SO}_{3} \mathrm{H}$ and SIS-SO ${ }_{3} \mathrm{H}$ were respectively $1.2 \times 10^{-3}$ and $3.2 \times 10^{-4} \mathrm{~S}$. $\mathrm{cm}^{-1}$ in an ambient atmosphere. The conductivities of PI$\mathrm{SO}_{3} \mathrm{H}$ and SIS-SO ${ }_{3} \mathrm{H}$ decreased by about two orders of magnitude in a dry $\mathrm{N}_{2}$ atmosphere than those in an ambient atmosphere.

Shore hardness and tensile stress of SIS base polymer were 52 and $204 \mathrm{~kg} / \mathrm{cm}^{3}$, respectively.

3.3 Proton conductivity of composite of $\mathrm{H}_{3} \mathrm{PO}_{4}$-doped silica gel and $\mathrm{PI}-\mathrm{SO}_{3} \mathrm{H}$

Figure 2 shows an example of the frequency-dependent complex impedance plot measured for the composite composed of $\mathrm{H}_{3} \mathrm{PO}_{4}$-doped silica gel and $\mathrm{PI}-\mathrm{SO}_{3} \mathrm{H}$. The plots were obtained at 23 and $45^{\circ} \mathrm{C}$ in an $\mathrm{N}_{2}$ atmosphere. The sulfonation ratio of the $\mathrm{PI}-\mathrm{SO}_{3} \mathrm{H}$ was $50 \%$. The composite was dried in vacuo at room temperature for $1 \mathrm{~h}$ just before the measurement and the amount of the PI-SO ${ }_{3} \mathrm{H}$ blended was 5 mass $\%$. A part of semicircle and a straight line are observed in the plot at $23^{\circ} \mathrm{C}$ and a straight line at $45^{\circ} \mathrm{C}$. It can be seen that bulk resistance of the composite corresponding to the intersection of plots with the real axis decreases with an increase in the measurement temperature.

We have showed in the preceding work that the conductivity of the composites composed of $\mathrm{H}_{3} \mathrm{PO}_{4}$-doped silica gels and an organic polymer significantly increased with an increase in the amount of $\mathrm{H}_{3} \mathrm{PO}_{4}$ added. ${ }^{12}$ ) This result indicates that the charge carrier of the composites must be proton dissociated mainly from the $\mathrm{H}_{3} \mathrm{PO}_{4}$, whereas the transport number of proton in the composites is probably smaller than unity.

Figure 3 shows the temperature dependence of ionic conductivities of composite composed of the $\mathrm{H}_{3} \mathrm{PO}_{4}$-doped silica gels and $\mathrm{PI}-\mathrm{SO}_{3} \mathrm{H}$ with different sulfonation ratios in dry $\mathrm{N}_{2}$. Closed diamonds, open squares, closed squares, open circles and closed circles represent the composites containing $\mathrm{PI}-\mathrm{SO}_{3} \mathrm{H}$ with sulfonation ratios of $0,5,10,30$ and $50 \%$, respectively. The amount of $\mathrm{PI}-\mathrm{SO}_{3} \mathrm{H}$ blended was 5 mass \% for all the composites in Fig. 3. The conductivities

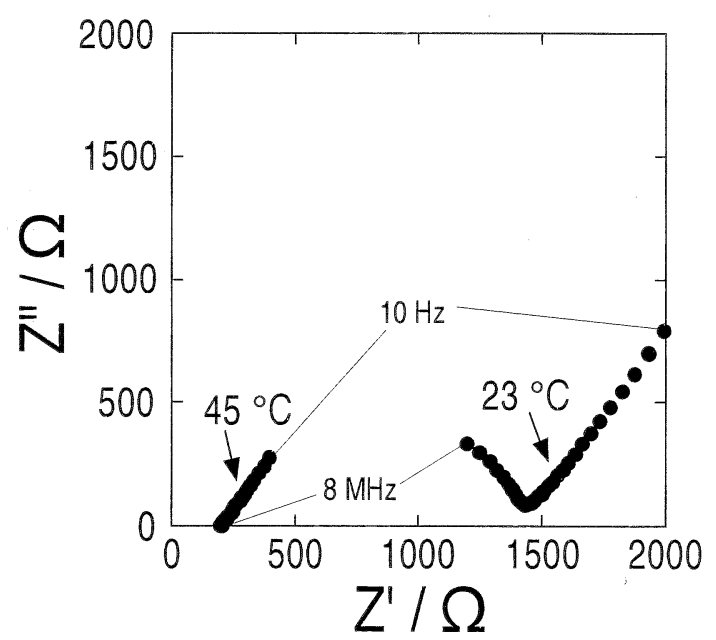

Fig. 2. Frequency-dependent complex impedance plots measured for the composite composed of $\mathrm{H}_{3} \mathrm{PO}_{4}$-doped silica gel and $\mathrm{PI}-\mathrm{SO}_{3} \mathrm{H}$ at 23 and $45^{\circ} \mathrm{C}$ in an $\mathrm{N}_{2}$ atmosphere. The sulfonation ratio of the $\mathrm{PI}-\mathrm{SO}_{3} \mathrm{H}$ was $50 \%$. The gel was dried in vacuo at room temperature for $1 \mathrm{~h}$ and the amount of the $\mathrm{PI}-\mathrm{SO}_{3} \mathrm{H}$ mixed was 5 mass $\%$.

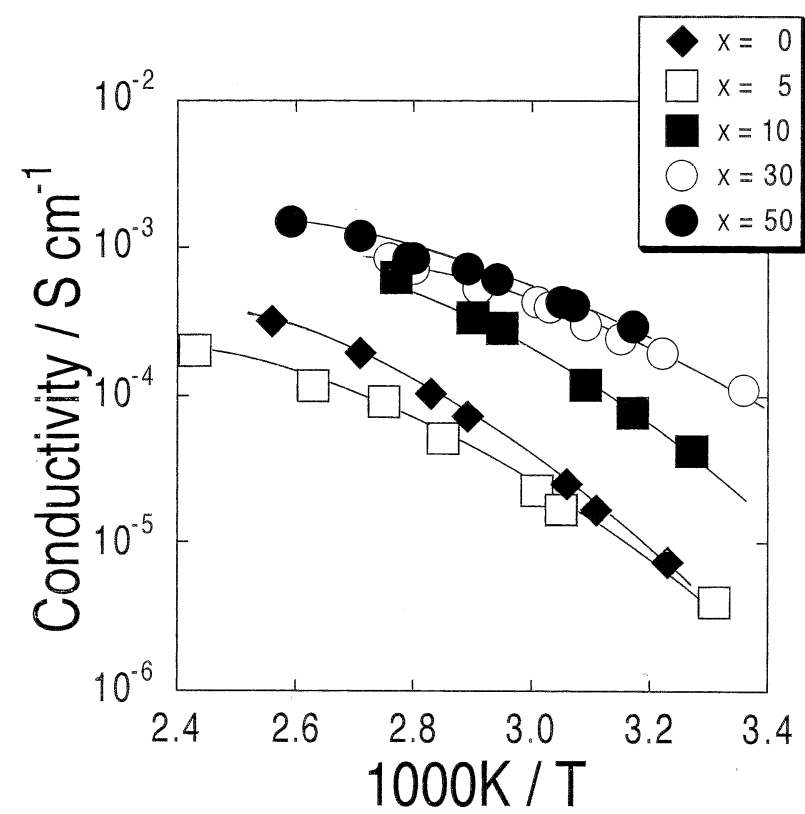

Fig. 3. Temperature dependence of ionic conductivities of composites composed of $\mathrm{H}_{3} \mathrm{PO}_{4}$-doped silica gel and $\mathrm{PI}-\mathrm{SO}_{3} \mathrm{H}$ with different sulfonation ratios. Closed diamonds, open squares, closed squares, open circles and closed circles represent the composites containing $\mathrm{PI}-\mathrm{SO}_{3} \mathrm{H}$ with sulfonation ratios of $0,5,10,30$ and $50 \%$, respectively. The amount of the $\mathrm{PI}-\mathrm{SO}_{3} \mathrm{H}$ blended was 5 mass $\%$ for all the composites. The conductivity of composites was measured in a dry $\mathrm{N}_{2}$ atmosphere during both heating and cooling runs in a temperature range from room temperature to $100^{\circ} \mathrm{C}$ after the composites were dried in vacuo at room temperature for $1 \mathrm{~h}$.

of the composites were measured during both heating and cooling runs in a temperature range from room temperature to $100^{\circ} \mathrm{C}$. It can be seen that the conductivities of the composites containing $\mathrm{PI}-\mathrm{SO}_{3} \mathrm{H}$ with sulfonation ratios of 30 and $50 \%$ are higher by one order of magnitude than those of composites containing $\mathrm{PI}-\mathrm{SO}_{3} \mathrm{H}$ with sulfonation ratios of 0 and $5 \%$. When the sulfonation ratio became larger than $10 \%$, sulfo groups in the $\mathrm{PI}-\mathrm{SO}_{3} \mathrm{H}$ may assist the proton transfer in the composites. The temperature dependence of conductivity of all the composites is not the Arrhenius type but the Vogel-Tamman-Fulcher type. ${ }^{15}$ Similar temperature dependence of conductivities has been observed so far for the composites composed of acid-doped silica gels and polyvinyl alcohol ${ }^{9)}$ and the composites acid-doped silica gels and styrene-ethylene-buthylene-styrene block copolymer. ${ }^{12)}$ Such a dependence of the conductivity indicates that proton transfers through a liquid-like phase present in micropores of the $\mathrm{H}_{3} \mathrm{PO}_{4}$-doped silica gels and/or between the gel granules.

The conductivity in dry $\mathrm{N}_{2}$ of the composite containing $\mathrm{PI}-\mathrm{SO}_{3} \mathrm{H}$ with a sulfonation ratio of $50 \%$ was found to increase by one order of magnitude after the storage in an atmosphere of $25 \%$ relative humidity at room temperature for one day. For example, the conductivity of the composite attained to $10^{-3} \mathrm{~S} \cdot \mathrm{cm}^{-1}$ at room temperature after the storage.

3.4 IR spectra of $\mathrm{PI}-\mathrm{SO}_{3} \mathrm{H}$ with adsorbed water

Figure 4 shows IR absorption spectra of PI without sulfonation (a) and $\mathrm{PI}-\mathrm{SO}_{3} \mathrm{H}$ with a sulfonation ratio of $50 \%$ (b). In Fig. 4 (a), absorption peaks at 1650 and $2900 \mathrm{~cm}^{-1}$ are assigned to stretching vibrations of $\mathrm{C}=\mathrm{C}$ bonds and $\mathrm{C}-$ $\mathrm{H}$ bonds, respectively. The doublet peaks at around 850 and $1400 \mathrm{~cm}^{-1}$ are assigned to deformation vibrations of C$\mathrm{H}$ bonds. On the other hand, peaks due to $-\mathrm{SO}_{2}-$ bonds are 


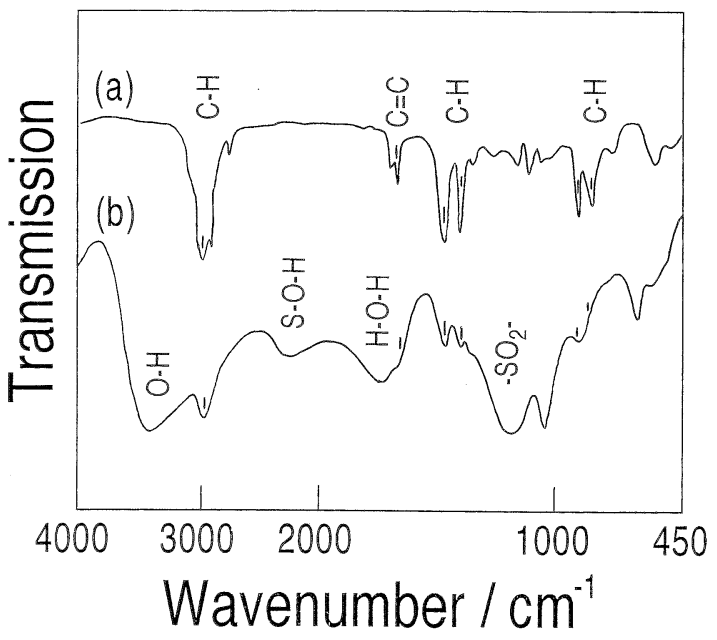

Fig. 4. IR absorption spectra of PI without sulfonation (a) and $\mathrm{PI}-\mathrm{SO}_{3} \mathrm{H}$ with a sulfonation ratio of $50 \%$ (b).

seen at around 1050 and $1200 \mathrm{~cm}^{-1}$ in Fig. 4(b). ${ }^{16)}$ Peaks at 1700 and $3500 \mathrm{~cm}^{-1}$ are assigned to the deformation vibration of $\mathrm{H}-\mathrm{O}-\mathrm{H}$ bonds and the stretching vibration of $\mathrm{O}-\mathrm{H}$ bonds in $\mathrm{H}_{2} \mathrm{O}$. In addition, a peak at $2300 \mathrm{~cm}^{-1}$, which is not observable for PI in Fig. 4(a), is clearly seen. The similar peak was also observed at around $2300 \mathrm{~cm}^{-1}$ for sulfuric acid, so that this peak must be due to $\mathrm{S}-\mathrm{O}-\mathrm{H}$ bonds. When the PI-SO ${ }_{3} \mathrm{H}$ was dried in vacuo at room temperature, the intensity of the peaks at 1700 and 3500 $\mathrm{cm}^{-1}$ due to $\mathrm{H}_{2} \mathrm{O}$ did not change. This result indicates that $\mathrm{H}_{2} \mathrm{O}$ is strongly adsorbed to $\mathrm{PI}-\mathrm{SO}_{3} \mathrm{H}$. The increase in conductivity of the composites with an increase in sulfonation ratio of PI and with storage in an ambient atmosphere can be ascribed to the increase in the amount of hydrated water, which probably forms liquid paths suitable for proton conduction.

3.5 Proton conductivity of composite of $\mathrm{H}_{3} \mathrm{PO}_{4}$-doped silica gel and $\mathrm{SIS}-\mathrm{SO}_{3} \mathrm{H}$

It was found from Fig. 2 that the conductivity of the composite containing $\mathrm{PI}-\mathrm{SO}_{3} \mathrm{H}$ increased with increasing the sulfonation ratio. The molding characteristics of the composite were, however, not so good, and the composite tore when a tensile stress was applied to the composite for the measurement of the thermomechanical properties. For the practical application of proton-conductive composites to electrochemical devices such as fuel cells, metal hydride batteries and supercapacitors, the improvement of molding properties to form sheet of membrane is indispensable. We have shown so far that SEBS elastomer provided the resultant composites with good molding characteristics due to its polystyrene part as a hard segment. ${ }^{12)}$ In the present work, we have designed the SIS-SO ${ }_{3} \mathrm{H}$, which is expected to assist the proton conduction in the composite as well as good molding characteristics due to the thermoplasticity.

Figure 5 shows an example of the frequency-dependent complex impedance plots measured for the composite composed of $\mathrm{H}_{3} \mathrm{PO}_{4}$-doped silica gel and $\mathrm{SIS}_{-} \mathrm{SO}_{3} \mathrm{H}$ with a sulfonation ratio of $20 \%$ at 32,48 , and $80^{\circ} \mathrm{C}$ in an $\mathrm{N}_{2}$ atmosphere. The amount of SIS- $\mathrm{SO}_{3} \mathrm{H}$ blended was 20 mass \%. The measurement was carried out in the frequency range from $10 \mathrm{~Hz}$ to $8 \mathrm{MHz}$. A semicircle and a straight line are observed in the plot at $48^{\circ} \mathrm{C}$. A part of semicircle is observable for the plot at $32^{\circ} \mathrm{C}$ and a straight line for $80^{\circ} \mathrm{C}$. The bulk resistance of the composite was obtained from the intersection of the semicircle with the real axis at a lower frequency and the intersection of the straight line with the real axis. It can be seen that the bulk resistance of the com-

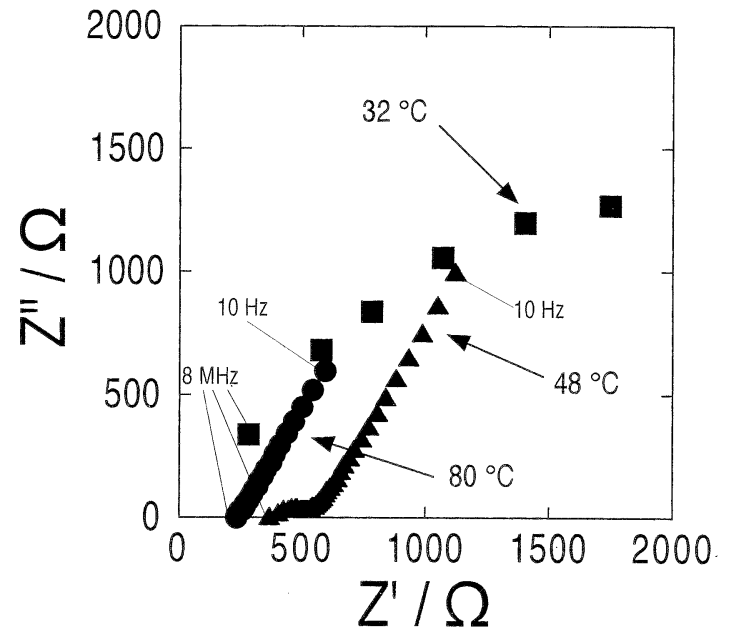

Fig. 5. Frequency-dependent complex impedance plots measured for the composite composed of $\mathrm{H}_{3} \mathrm{PO}_{4}$-doped silica gei and SIS-SO $\mathrm{S}_{3} \mathrm{H}$ with a sulfonation ratio of $20 \%$ at 32,48 , and $80^{\circ} \mathrm{C}$ in an $\mathrm{N}_{2}$ atmosphere. The amount of SIS- $\mathrm{SO}_{3} \mathrm{H}$ blended was 20 $\operatorname{mass} \%$.

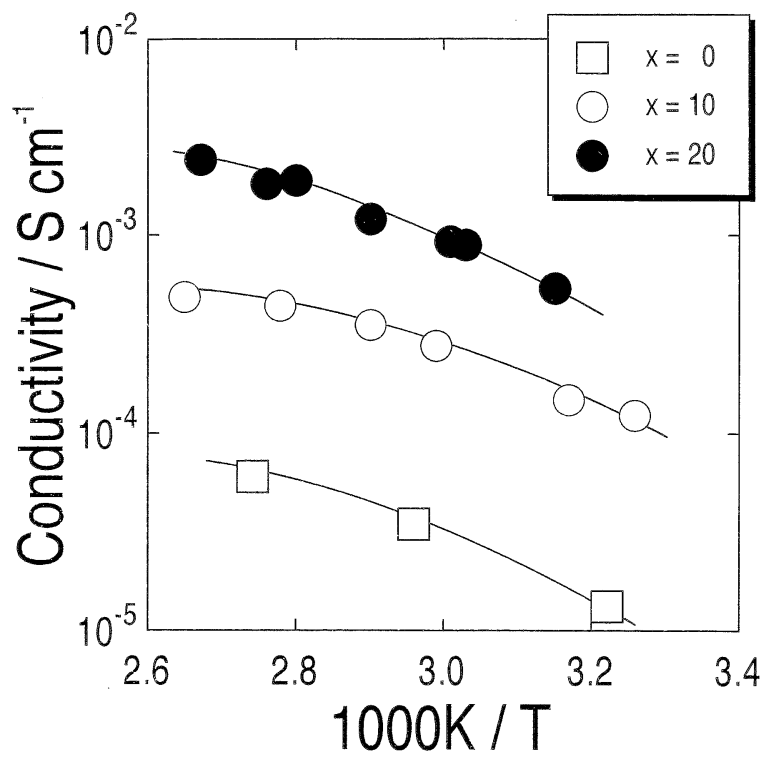

Fig. 6. Temperature dependence of ionic conductivities of the composites composed of $\mathrm{H}_{3} \mathrm{PO}_{4}$-doped silica gel and $\mathrm{SIS}-\mathrm{SO}_{3} \mathrm{H}$. The amount of SIS- $\mathrm{SO}_{3} \mathrm{H}$ was fixed to be 20 mass $\%$. In this figure, $x$ represents the sulfonation ratio in $\%$ of $\mathrm{SIS}_{-} \mathrm{SO}_{3} \mathrm{H}$. The conductivity of composites was measured in a dry $\mathrm{N}_{2}$ atmosphere during both heating and cooling runs immediately after the composites were dried in vacuo at room temperature for $1 \mathrm{~h}$.

posite decreases with an increase in the measurement temperature.

Figure 6 shows the temperature dependence of ionic conductivities of the composites composed of $\mathrm{H}_{3} \mathrm{PO}_{4}$-doped silica gel and $\mathrm{SIS}_{-} \mathrm{SO}_{3} \mathrm{H}$ elastomer. The amount of SIS$\mathrm{SO}_{3} \mathrm{H}$ blended was fixed to be 20 mass $\%$. In this figure, $x$ represents the sulfonation ratio in \% of $\mathrm{SIS}-\mathrm{SO}_{3} \mathrm{H}$. The conductivity of composites was measured in a dry $\mathrm{N}_{2}$ atmosphere during both heating and cooling runs immediately after the composites were dried in vacuo at room temperature for $1 \mathrm{~h}$. At a given temperature, the conductivity of the composites increases with increasing $x$, indicating that sulfo groups in SIS- $\mathrm{SO}_{3} \mathrm{H}$ similar to $\mathrm{PI}-\mathrm{SO}_{3} \mathrm{H}$ accelerate the proton transfer. The temperature dependence 
of all the composites is roughly the Vogel-TammanFulcher type ${ }^{15}$ ) as well as that of the composite with PI$\mathrm{SO}_{3} \mathrm{H}$. This result reflects the fact that most of $\mathrm{H}_{3} \mathrm{PO}_{4}$ added to silica gels is present as a liquid-like phase in pores filled with adsorbed water in silica gel as shown in Fig. 1.

3.6 The thermomechanical properties of the composites

When a tensile stress was applied to the composite containing $\mathrm{PI}-\mathrm{SO}_{3} \mathrm{H}$ for the measurement of the thermomechanical properties, the composite tore due to its poor molding characteristics. On the other hand, the composites containing SIS- $\mathrm{SO}_{3} \mathrm{H}$ exhibited a thermoplastic elasticity and good molding characteristics, so that sheets of the highly proton conductive composite were obtained. The elastic modulus of the composites was measured to discuss the influence of the blend of the elastomer to the $\mathrm{H}_{3} \mathrm{PO}_{4}$ doped silica gel.

Figure 7 shows temperature dependence of thermomechanical properties of SIS itself (a) and composite containing SIS- $\mathrm{SO}_{3} \mathrm{H}$ in 20 mass $\%$ (b). The sulfonation ratio of the SIS-SO ${ }_{3} \mathrm{H}$ was $20 \%$. Open and closed circles represent the elastic modulus and loss energy, respectively. The elastic modulus and loss energy of SIS-SO ${ }_{3} \mathrm{H}$ at room temperature are respectively $2.7 \times 10^{6} \mathrm{~Pa}$ and $2.1 \times 10^{-7} \mathrm{~J}$,
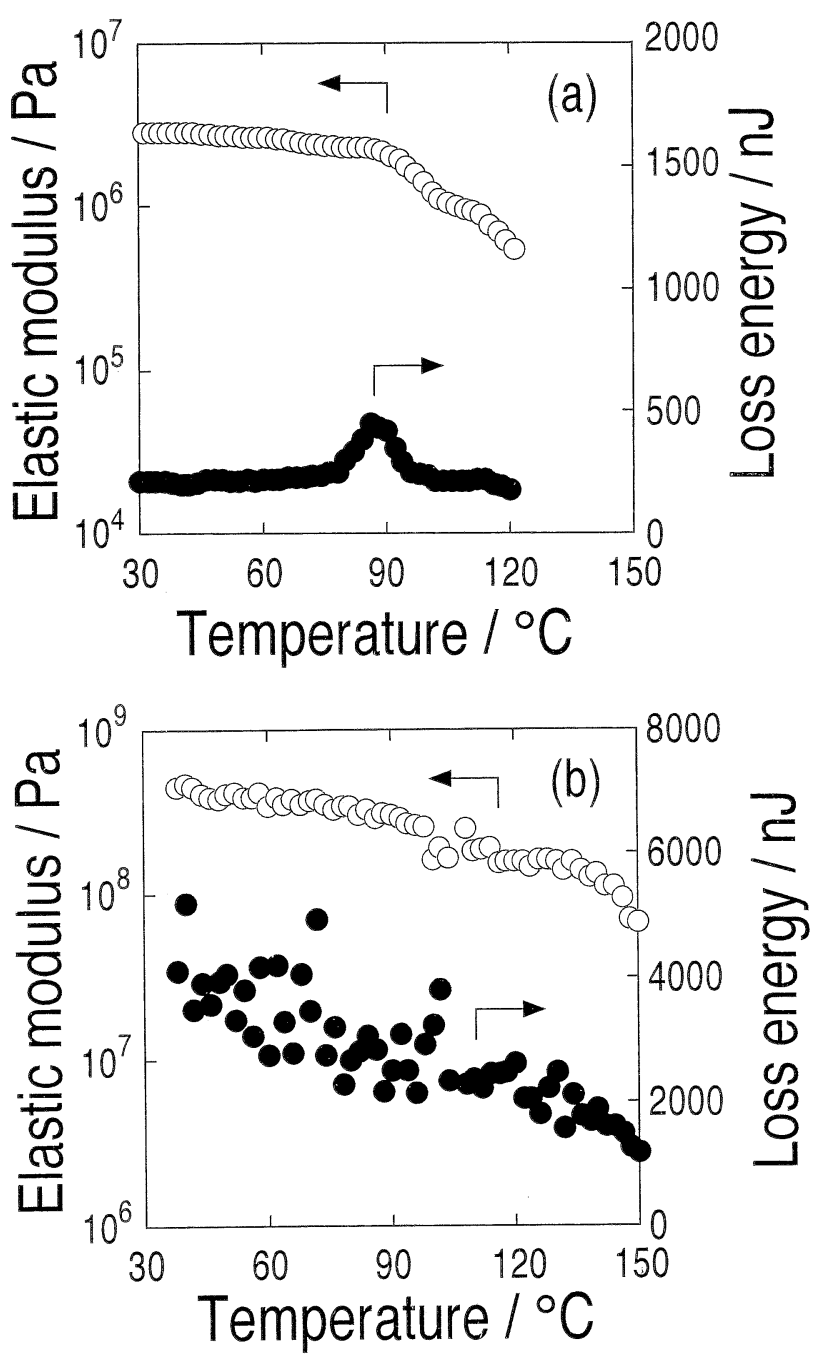

Fig. 7. Temperature dependence of thermomechanical properties of SIS itself (a) and composite containing SIS-SO ${ }_{3} \mathrm{H}$ in 20

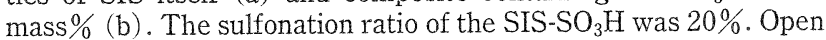
and closed circles represent the elastic modulus and loss energy, respectively. whereas those of the composite are $4.6 \times 10^{8} \mathrm{~Pa}$ and $4.1 \times$ $10^{-5} \mathrm{~J}$. The temperature dependences of the modulus and loss of the composite were similar to those of the SIS- $\mathrm{SO}_{3} \mathrm{H}$. For the SIS-SO ${ }_{3} \mathrm{H}$, a drop of modulus and a peak in loss energy are seen at around $80^{\circ} \mathrm{C}$, which corresponds to the thermoplastically deforming temperature of the elastomer. The drop of modulus is observed around $130^{\circ} \mathrm{C}$ for the composite, indicating that the thermoplastically deforming temperature is increased by $50^{\circ} \mathrm{C}$ due to the homogeneous blending of the gels with $\mathrm{SIS}-\mathrm{SO}_{3} \mathrm{H}$. The inorganic gel grains must prevent the softening of SIS- $\mathrm{SO}_{3} \mathrm{H}$ at higher temperatures than its intrinsic thermoplastically deforming temperature. Large fluctuation is seen in loss energy for the composite and the peak corresponding to thermoplastically deforming temperature is not clearly observed. This large fluctuation is probably caused by the energy loss due to heat of vaporization of adsorbed water.

3.7 Electric double-layer capacitor using composites as a solid electrolyte

The cyclic voltammogram of the capacitor fabricated using the composite composed of $\mathrm{H}_{3} \mathrm{PO}_{4}$-doped silica gel and SIS- $\mathrm{SO}_{3} \mathrm{H}$ as an electrolyte and $\mathrm{ACP}$ as a polarizable electrode showed the typical capacitive current curve in a sweep region of +0.4 to $-0.4 \mathrm{~V}$. This result demonstrates that electric charge was stored in the electric double-layer at the interface between the polarizable electrode and the electrolyte in spite of its totally solid state structure. No redox peaks were observed in the sweep region and the cyclic voltammogram was unchanged with repeated runs.

Figure 8 shows the comparison of discharge curves measured in (a) dry $\mathrm{N}_{2}$ and (b) ambient air atmospheres at room temperature for the capacitor fabricated. The capacitor was charged by applying a constant dc voltage of $0.5 \mathrm{~V}$ for $30 \mathrm{~min}$ at room temperature before the measurement. Both in (a) dry $\mathrm{N}_{2}$ and (b) ambient air atmospheres the voltage drop during discharge of the capacitor increases with an increase in the discharge current. It can be seen that voltage drop during discharge in ambient air (b) is

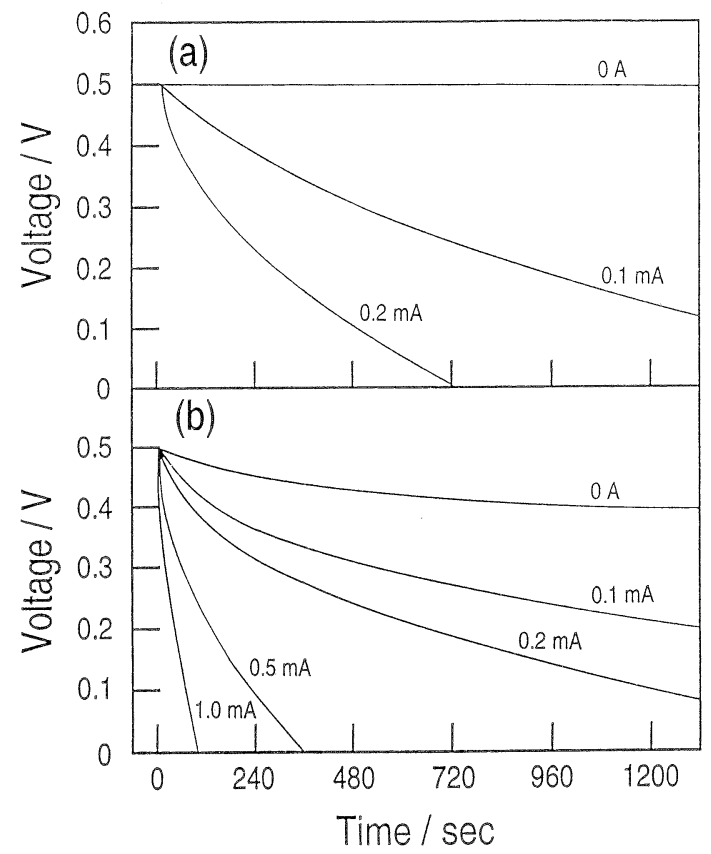

Fig. 8. Comparison of discharge curves measured in (a) dry $\mathrm{N}_{2}$ and (b) ambient air atmospheres at room temperature for the capacitor fabricated. The capacitor was charged by applying a constant dc voltage of $0.5 \mathrm{~V}$ for $30 \mathrm{~min}$ at room temperature before the measurement. 
Table 2. Resistances Calculated from Complex Impedance and IR-Drop and Capacitances (a) in Dry $\mathrm{N}_{2}$ and (b) in Air of the Electric Double-Layer Capacitor with ACP and the Composite Composed of $\mathrm{H}_{3} \mathrm{PO}_{4}$-Doped Silica Gel and SIS-SO $\mathrm{S}_{3} \mathrm{H}$ at Room Temperature

\begin{tabular}{cccc}
\hline Atmosphere & $R($ imp.) $/ \Omega$ & $R($ IR-drop) $/ \Omega$ & $C / F^{-1}$ \\
\hline (a) Dry $\mathrm{N}_{2}$ & 2530 & 2710 & 3 \\
(b) Air & 48 & 53 & 12 \\
\hline
\end{tabular}

smaller than that in dry $\mathrm{N}_{2}$ (a). This result corresponds to the drastic decrease in the resistance of the capacitors due to the water adsorption to the composite in an ambient atmosphere. Voltage drops by $1 \%$ and $20 \%$ in $1200 \mathrm{~s}$ under a discharge current of $0 \mathrm{~A}$ are observed in (a) dry $\mathrm{N}_{2}$ and (b) ambient air atmospheres, respectively. One of the most important factors which cause these voltage drops should be a leak current through the side area of the three layered tablet capacitor. Perfect insulation between a pair of polarizable electrode layers in capacitors is, thus, required to diminish the current leakage. The increase in the amount of adsorbed water in the capacitor in an ambient atmosphere might facilitate the formation of paths for leakage.

The dc resistance of a capacitor can be estimated by voltage drop, IR-drop, at the beginning of discharge process of the capacitors. Since IR-drop was proportional to the discharge current $I, R$ (IR-drop) of the capacitor can be obtained. The capacitance, $C$, of capacitors can also be given by $(I t) / V$, where $I$ is the constant discharge current, $t$ is the time for discharge, and $V$ is the potential change of the capacitor caused by discharge. ${ }^{17)}$ The values of $R$ (IRdrop) and $C$ calculated are listed in Table 2 together with resistance obtained from complex impedance plot, $R$ (imp.), in a dry $\mathrm{N}_{2}$ atmosphere and in an ambient air atmosphere at room temperature. Both in dry $\mathrm{N}_{2}$ and in ambient air atmospheres, the values of $R$ (imp.) are comparable to those of $R$ (IR-drop). The value of $C$ / (gram of total ACP) of the capacitor in an ambient atmosphere is four times larger than that of the capacitor in dry $\mathrm{N}_{2}$ and comparable to those of the conventional capacitors with liquid electrolytes. ${ }^{18)}$ The large capacitance of the totally solid electric doublelayer capacitors fabricated is attributable to the sufficient formation of electric double-layer at the interface between the highly proton conductive silica gel and ACP.

\section{Conclusion}

We have prepared composites composed of $\mathrm{H}_{3} \mathrm{PO}_{4}$-doped silica gel and sulfonated organic polymers and investigated the proton conductivity and thermoelastic properties of the composites.

The conductivities of the composites containing $\mathrm{PI}-\mathrm{SO}_{3} \mathrm{H}$ and $\mathrm{SIS}-\mathrm{SO}_{3} \mathrm{H}$ increased with an increase in the sulfonation ratio, so that sulfo groups must assist the proton transfer in the composites. The temperature dependence of conductivity of all the composites was not the Arrhenius type but the Vogel-Tamman-Fulcher type, indicating that proton transferred through a liquid-like phase present in micropores of the $\mathrm{H}_{3} \mathrm{PO}_{4}$-doped silica gels and/or between the gel granules.

From the $I R$ absorption spectra, the increase in conductivity of the composites with an increase in sulfonation ratio was ascribed to the increase in the amount of hydrated water, which forms the liquid paths suitable for proton conduction.

The composites containing SIS- $\mathrm{SO}_{3} \mathrm{H}$ exhibited not only a high proton conductivity but also good molding characteristics due to its thermoplastic elasticity, so that sheets of the highly proton conductive composite were obtained. For the composite, thermoplastically deforming temperature was observed around $130^{\circ} \mathrm{C}$, indicating that the thermoplastic property was improved by $50^{\circ} \mathrm{C}$ due to the homogeneous blending of the gel with SIS- $\mathrm{SO}_{3} \mathrm{H}$.

We have succeeded in fabrication of the totally solid electric-double layer capacitors using the composite as an electrolyte and ACP as polarizable electrode. The value of capacitance of the capacitor in an ambient atmosphere was $12 \mathrm{~F}$ / (gram of total ACP), which was four times larger than that of the capacitor in dry $\mathrm{N}_{2}$. The large capacitance in an ambient atmosphere should be attributable to the formation of electric double-layer with sufficient electricity at the interface between the composite and ACP due to the water adsorption, which allowed the interface to form paths suitable for fast proton transport.

The composite fabricated in the present study is promising as a proton conductive solid electrolyte not only for electric double-layer capacitors but also for fuel cells and metal hydride batteries. The fundamental characteristics of the composites are now under study aiming at the application to the above electrochemical power devices.

Acknowledgment This work was supported by the "Research for the Future Program" from the Japan Society for the Promotion of Science and by the Grant-in-Aid for Scientific Research on Priority Areas (B) from the Ministry of Education, Culture, Sports and Science. We thank Y. Takeuchi and K. Bessho of JRS Co., Ltd. for synthesis and supply of PI-SO ${ }_{3} \mathrm{H}$ and SIS-SO ${ }_{3} \mathrm{H}$. We also thank Y. Kotani and T. Kanzaki for their technical support.

\section{References}

1) Ph. Colomban, Ann. Chim. Sci. Mater., 24, 1-18 (1999).

2) I. Gautier-Luneau, A. Denoyelle, J. Y. Sanchez and C. Poinsignon, Electrochem. Acta, 37, 1615-18 (1992).

3) N. Kuriyama, T. Sakai, H. Miyamura and H. Ishikawa, Solid State Ionics, 53-56, 688-93 (1992).

4) A. Nishino, J. Power Sources, 60, 137-47 (1996).

5) M. Nogami, K. Miyamura and Y. Abe, J. Electrochem. Soc., 144, 2175-78 (1997).

6) M. Tatsumisago and T. Minami, J. Am. Ceram. Soc., 72, 484-86 (1989).

7) M. Tatsumisago, Y. Sakai, H. Honjo and T. Minami, $J$. Ceram. Soc. Japan, 103, 189-90 (1995).

8) M. Tatsumisago, H. Honjo, Y. Sakai and T. Minami, Solid State Ionics, 74, 105-08 (1994).

9) A. Matsuda, H. Honjo M. Tatsumisago and T. Minami, Chem. Lett., 1189-90 (1998).

10) H. Honjo, M. Tatsumisago and T. Minami, J. Mater. Sci. Lett., 14, 783-84 (1995).

11) A. Matsuda, H. Honjo, M. Tatsumisago and T. Minami, Solid State Ionics, 113-115, 97-102 (1998).

12) K. Hirata, A. Matsuda, T. Hirata, M. Tatsumisago and T. Minami, J. Sol-Gel Sci. Tech., in press.

13) A. Matsuda, H. Honjo, K. Hirata, M. Tatsumisago and $T$. Minami, J. Power Sources, 77, 12-17 (1999).

14) C. Fernandes-Lorenzo, L. Esquivias, P. Barboux, J. Maquet and F. Taulelle, J. Non-Cryst. Solids, 176, 189-99 (1994).

15) F. M. Gray, J. R. MacCallum, C. A. Vincmt and J. R. M. Giles, Macromolecules, 21, 392-97 (1988).

16) S. D. Ross, "Inorganic Infrared and Raman Spectra," Ed. by P. Sykes, McGraw-Hill, London (1972) pp. 224-26.

17) M. Morita, M. Goto and Y. Matsuda, J. Appl. Electrochem., 22, 901-08 (1992).

18) I. Tanahashi, A. Yoshida and A. Nishino, Bull. Chem. Soc. Japan, 63, 3611-14 (1990). 